\title{
The exhaustion of patent rights $v$ the implied licence approach: untangling the web of patent rights
}

\author{
Jessica C Lai \\ Senior Lecturer, Victoria University of Wellington, New Zealand
}

This article analyses and compares the two main approaches that deal with the relationship between patent exclusive rights and the artefacts embodying patented inventions (usually chattel). Namely, it examines the implied licence approach and the exhaustion approach, at the national and international level, and extrapolates the scope of patent exclusive rights under these two models. The article uses the international dimension to highlight that having two approaches complicates international trade and that this is exacerbated by the nature of the exclusive rights themselves. Highlighting the fact that several exclusive rights only exist upon embodiment, do not marry up to the invention as claimed, and are - for all intents and purposes - served by rights in choses in possession, the article argues that several patent exclusive rights have no practical purpose. The article suggests a simplified approach to patent exclusive rights and thereby the relationship between patented inventions and their physical embodiments.

Keywords: patent rights, exhaustion, implied licence

\section{INTRODUCTION}

Intellectual property rights are territorial, except when they are not. We see this in all different areas of intellectual property. For example, though a patent is granted for a specific jurisdiction (or a region), ${ }^{1}$ the interpretation of patent rights and ergo infringement can result in either looking at extraterritorial actions or patents having extraterritorial effects. At the same time, the confluence of a high degree of implementation of international copyright obligations, the internet and digital technologies, and the fact that one need not apply/register for copyright protection, has resulted in copyright being pseudo international in nature. Additionally, while trade marks are about local markets and consumers, international trade and multinational companies with complex relational structures have blurred jurisdictional borders. $^{2}$ Two quotes from a passing-off case regarding Champagne in New Zealand exemplify this well: ${ }^{3}$

1. There is no 'international patent'. There are regional patent offices, see $<$ http://www.wipo. int/patents/en/topics/worksharing/regional-patentoffices.html>.

2. S Frankel, Intellectual Property in New Zealand, 2nd edn (LexisNexis, Wellington 2011) at $104-9$.

3. Wineworths $v$ Comite Interprofessionel du Vin de Champagne (1992) 2 NZLR 327 at 344 Gault J. 
Similarly against a background in which the name 'Champagne' is shown clearly to have different significance in different countries I cannot see the relevance of this to New Zealand litigation.

That is, we are only interested in the territory of New Zealand. However: ${ }^{4}$

one trusts that the Champagne houses are alive to the risk that conduct on their part undermining distinctiveness in some jurisdictions could have a flow-on effect in others. There may be limits to the naïveté of a New Zealand Court.

Put another way, we cannot be blind to the fact that the world is becoming flatter.

Many of the extraterritorial facets of intellectual property are obviously caused by international trade, and the international discourse on territoriality and exhaustion has been simmering in recent years. As a result, much of the literature pertaining to territoriality, patent rights and infringement deals with parallel importing. ${ }^{5}$ Rather than focusing on parallel importing or international trade, this article analyses and compares the two main approaches that deal with the relationship between patent exclusive rights and the artefacts embodying patented inventions (usually chattel). Namely, the implied licence approach and the exhaustion approach. It uses the international dimension to highlight that having two approaches complicates international trade and that this is exacerbated by the nature of the exclusive rights themselves.

The following sections examine the exhaustion approach and the implied licence approach. The article then compares the two approaches, and highlights the complexities created by having two models in a global world and certain rights that only exist upon embodiment. Section 4 of the article attempts to untangle the complexities and suggests a simplified approach.

\section{THE MODELS}

Patents are a type of intellectual property, though their nature as 'property' continues to be debated. ${ }^{6}$ If the subject matter of the patent is a product, the patent owner is typically endowed with the exclusive rights to make, use, offer to sell, sell and import the invention. ${ }^{7}$ If the subject matter of the patent is a process, the patent owner has the exclusive

4. Ibid, at 333 Cooke P.

5. For an overview of parallel importing and intellectual property, see I Calboli and E Lee (eds), Research Handbook on IP and Exhaustion (Edward Elgar, Cheltenham 2017). See also S Frankel and D Gervais, Advanced Introduction to International Intellectual Property (Edward Elgar, Cheltenham 2016) at 114-16; Frankel (n 2) at 89-93; and S Frankel and JC Lai, Patent Law and Policy (LexisNexis 2016) at 72-7.

6. See, for example, HR Howe and J Griffiths (eds), Concepts of Property in Intellectual Property Law (CUP, Cambridge 2013). On the transition from privileges to rights, see M Biagioli, 'Patent Specification and Political Representation: How Patents Became Rights', in M Biagioli, P Jaszi and M Woodmansee (eds), Making and Unmaking Intellectual Property: Creative Production in Legal and Cultural Perspectives (University of Chicago Press, Chicago 2011) 25.

7. For example, WTO, Agreement on Trade Related Aspects of Intellectual Property Rights (TRIPS), Marrakesh Agreement Establishing the World Trade Organization, Annex 1C, 1869 UNTS 299; 33 ILM 1197 (adopted on 15 April 1994, entered into force 1 January 1995), Article 28(1); 35 USC § 271(a); and Patents Act 2013 (NZ), section 18(2)(a). 
right to use the process, and to use, offer to sell, sell or import any products made with the patented process. ${ }^{8}$

Given the exclusive rights of patentees, why is it that when one buys a cell phone embodying thousands of patents, one can use that cell phone or on-sell it and not be impinging upon any patent rights? But why is it that the purchaser cannot take the cell phone apart, reverse-engineer it and reproduce it? Of course, if the cell phone did not include any patented inventions (or other intellectual property), the purchaser could reproduce it.

At the heart of this is the relationship between patent rights and rights over chattel, or - put differently - rights over the intangible invention and rights over its tangible embodiment. This relationship is defined by the concepts of 'first sale' and 'exhaustion' in the US and in Europe. In the UK, Canada, Australia and New Zealand, standard property law regarding choses in possession, and explicit/implied licences regarding the embodied intellectual property, regulate the relationship. ${ }^{9}$ Parallel importing pertains to this relationship on an international scale.

One often reads that 'all patent rights' are exhausted. ${ }^{10}$ However, it is only the rights to use, sell and import which can exhaust or are covered by an implied licence. The right to make is not included. ${ }^{11}$ This is only logical. Just because one buys a product embodying a patented invention does not mean that one can then make the patented invention. One is entitled to use and on-sell the chattel (and thereby use and sell the embodied patented invention), but not make the invention. This is the same in copyright, where purchasers of copies of a book can use their physical copies in any way they wish, including on-selling them, but cannot copy the underlying copyright-protected work. ${ }^{12}$ If this were not the case and purchasers were entitled to make and sell reproductions, the benefits of a patent would essentially be over after a single (or a few) sales. This would curtail the reward to patentees for their invention and, thus, also diminish the patent incentive. ${ }^{13}$ In other words, if the purchaser of an embodiment of a patented invention could make the invention, patents would not offer enough of an incentive to invest in invention. ${ }^{14}$

8. For example, TRIPS (n 7) Article 28(2); 35 USC $\S 271(\mathrm{~g})$; and Patents Act 2013 (NZ), section $18(2)(b)$.

9. On the differences between the two approaches, see C Heath, 'Exhaustion and Patent Rights' in RL Okediji and MA Bagley, Patent Law in Global Perspective (OUP, Oxford 2014) 419 at 421-4; and C Heath, 'Patent Exhaustion Rules and Self-Replicating Technologies' in Calboli and Lee (n 5) 289 at 290-2.

10. For example, Impression Products v Lexmark, 581 US (2017) (Lexmark) at 5-6 Roberts CJ.

11. See Bowman v Monsanto, 33 S Ct 1761 (2013), 569 US

12. For a solid discussion on the exhaustion of copyright and the relationship between copyright and its physical embodiments, see A Perzanowski and J Schultz, 'Reconciling Intellectual Property and Personal Property' (2015) 90(3) Notre Dame L Rev 1211; and A Perzanowski and J Schultz, 'Digital Exhaustion' (2011) 58 UCLA L Rev 889.

13. Bowman v Monsanto (n 11) at 5-8.

14. On the 'incentive'-related aspects of exhaustion, see S Ghosh, 'Incentives, Contracts, and Intellectual Property Exhaustion' in Calboli and Lee (n 5) 3. See also SR Wasserman Rajec, 'Regulatory Responses to International Patent Exhaustion' in Calboli and Lee (n 5) 271, who discusses the relationship between international exhaustion, incentives, competition and the pharmaceuticals industry in the US. 


\subsection{The exhaustion model}

The exhaustion model is conceptually distinct from the licence approach. It dictates that certain patent rights cease to exist upon a specific action taking place, such as a legitimate sale of an embodiment. Underlying the exhaustion model is the idea that only one party - either the patentee or the vendee - can have certain rights over an artefact. Certain patent rights 'exhaust', so that the owner of the chattel can then undertake certain acts without infringing on the patent exclusive rights (Table 1). ${ }^{15}$

More conceptually, exhaustion is premised on the basis that a patent gives its owner one opportunity to obtain a reward vis-à-vis an artefact embodying a patented invention, under the conditions created by the existence of the patent (not necessarily monopolistic, but perhaps restricting of competition). Once that reward has been obtained, certain patent rights of the owner exhaust. At the domestic level, this is often referred to as the 'first-sale doctrine' especially in the US. Christopher Heath has noted that this is misleading, as exhaustion might be triggered by 'putting into commerce' or 'first marketing', which is broader than the act of sale. ${ }^{16}$

The exhaustion approach is taken in Continental Europe and the US, as well as in other jurisdictions. ${ }^{17}$ The way in which exhaustion is regulated is by no means uniform. For example, there are variances with respect to: whether one can contract out of exhaustion; whether exhaustion is national, regional or international; and the actions that dictate exhaustion.

Table 1 The exhaustion model

\begin{tabular}{|c|c|c|c|c|c|c|}
\hline Subject matter & $\begin{array}{l}\text { Patent rights } \\
\text { upon sale }\end{array}$ & Make & $\begin{array}{l}\text { Use (inc. } \\
\text { import, } \\
\text { keep) }\end{array}$ & Exercise & $\begin{array}{l}\text { Vend/sell, } \\
\text { dispose }\end{array}$ & Hire \\
\hline \multirow{2}{*}{$\begin{array}{l}\text { Artefact embodying the } \\
\text { invention (inc. resulting } \\
\text { from a process invention) }\end{array}$} & $\begin{array}{l}\text { Patentee's } \\
\text { remaining } \\
\text { rights }\end{array}$ & $\checkmark$ & - & $\checkmark$ & - & - \\
\hline & $\begin{array}{l}\text { Purchaser's } \\
\text { rights }\end{array}$ & - & $\checkmark$ & N/A & $\checkmark$ & $\checkmark$ \\
\hline
\end{tabular}

15. Lexmark (n 10) at 1 and 6-8 Roberts CJ.

16. Heath, 'Exhaustion and Patent Rights' (n 9) at 461.

17. Susy Frankel and Daniel J Gervais have noted that the term 'first-sale doctrine' should not be used synonymously with exhaustion, because it conflates the domestic and international aspects of distribution and makes it difficult to discuss how actions affect different rights from different jurisdictions and, thus, the distinction between domestic and international exhaustion; 'International Intellectual Property Rules and Parallel Imports' in Calboli and Lee (n 5) 85 at $88-9$.

Heath classified the 'first-sale doctrine' as conceptually distinct from the licence model and from the exhaustion approach; see Heath, 'Exhaustion and Patent Rights' (n 9) at 433-4. However, his categorization was largely based on the fact that patentees could contract out of exhaustion, which he saw as making the US approach something between an exhaustion and a licence approach. As discussed further in this text, this is no longer the case (Lexmark (n 10)). 


\subsubsection{The European Union}

The free movement of goods within the EU means that all EU Member States must have regional exhaustion. ${ }^{18}$ This dictates that the legal placement of a product embodying a patented invention on the market in the EU exhausts all patent rights in all EU Member States. This is the case even if there is no relevant patent in the country where the good is first marketed. ${ }^{19}$ For example, say a patentee has patents in Germany, Switzerland, the Netherlands and France, but not Italy - if the patentee places an embodiment of the patented invention on the Italian market, that embodiment can be marketed throughout the EU, including in Germany, Switzerland, the Netherlands and France, despite the fact that no Italian patent rights exhausted. That is, regional exhaustion is not dependant on the exhaustion of parallel rights in the jurisdiction of initial marketing.

What is important is that the patentee chose to place the embodiment on the market. There would, thus, be no regional exhaustion if the artefact was manufactured under a compulsory licence, ${ }^{20}$ if it was not the patentee who placed the artefact on the EU market (or the patentee did not consent to this), or the patentee was legally obliged to place the good on the market. ${ }^{21}$ The situation where pharmaceuticals are subsidized in a Member State, or there is an 'ethical' obligation to market in a Member State where the pharmaceutical is patent free, is more complicated. ${ }^{22}$

One cannot contract out of patent exhaustion and the courts have, generally, been wary of attempts to bypass exhaustion via the use of a licence or lease instead of a sale. ${ }^{23}$ Not being able to contract out of exhaustion reflects a more 'purest' form of exhaustion, consistent with the policy-based conceptualisation of patents as conferring the opportunity for a single reward per artefact. ${ }^{24}$

However, it is up to the individual Member States whether they wish to have international exhaustion (beyond the region). ${ }^{25}$ International exhaustion would mean that

18. Treaty on European Union and the Treaty on the Functioning of the European Union Consolidated version, OJ C 326 , 26/10/2012 P. 0001 - 0390, Articles 34 and 36. See also CM Stothers, 'The European Internal Market: Exhaustion Plus' in Calboli and Lee (n 5) 169. 19. Merck v Stephar and Exler (1981) ECR 2063 (ECJ Case 187/80); and Merck v Primecrown; Beecham v Europharm (1996) ECR I-6285 (ECJ Cases C-267/95 and C-268/95).

20. Pharmon BV v Hoechst AG (1985) ECR 2281 (ECJ Case 19/84) at [25].

21. Merck v Primecrown; Beecham v Europharm (1996) ECR I-6285 (ECJ Cases C-267/95 and $\mathrm{C}-268 / 95)$ at $[50]$.

22. See Merck v Primecrown; Beecham v Europharm (n 19) at [46] and [53].

23. Heath, 'Exhaustion and Patent Rights' (n 9) at 459-62.

24. On the circumvention of patent exhaustion in the US, see JF Duffy and R Hynes, 'Statutory Domain and the Commercial Law of Intellectual Property' (2016) 102(1) Va L Rev 1, at 53-64 and 73-76. Duffy and Hynes opine that exhaustion is not a result of policy reasoning, but a demarcation of patent law vis-à-vis other areas of commercial law, such as contract and chattel property law. They state (at 76) that: 'Commentators arguing for broad preemption make the same error that IP owners make in arguing against exhaustion. Both want IP law to expand into, and to displace, the ordinary commercial law governing the trade of physical goods. True, the outcomes sought by each group are diametrically opposed. Pro-preemption commentators want IP law to diminish commercial law rights; IP owners want to augment such rights. But the two positions share the overarching intellectual similarity of seeking to expand IP law. The core policy of exhaustion is the opposite - it is to confine the ambit of IP law ...'.

25. On the relationship between competition law and parallel importing in the EU, see J Drexl, 'Patent Exhaustion and Free Transit at the Interface of Public Health and Innovation Policies: Lessons to be Learned from EU Competition Law Practice' in Calboli and Lee (n 5) 249. 
the placement of the good anywhere in the world would exhaust the rights to use and sell for all relevant patents. As implied above, it is possible to require that international exhaustion only occurs if the first marketing is in a jurisdiction that has a relevant patent. That is, if there is exhaustion with respect to Patent ABC in Country $\mathrm{X}$, there is parallel exhaustion with respect to Patent ABC in Country Y. However, if Country $\mathrm{X}$ does not have a patent for $\mathrm{ABC}$, then one cannot say that there are parallel rights, and there is no exhaustion vis-à-vis Patent $\mathrm{ABC}$ in Country Y. The reason why a jurisdiction might require that the first marketing be in a country where there is a relevant patent is that - arguably - the patentee can only capture an appropriate payment (or reward) in a patent-existing environment. ${ }^{26}$ As noted, the EU regional exhaustion does not require that the invention was patented in the place of first marketing.

Although the UK otherwise retains a licence approach (as discussed below), ${ }^{27}$ it is subject to the EU's regional exhaustion. The regional exhaustion limits the ability of patentees in the UK (or anywhere in the EU) to counter the implied licence (or otherwise override regional exhaustion). ${ }^{28}$ That being said, the relationship between the UK's licence approach and the EU's regional exhaustion is by no means clear-cut. ${ }^{29}$

\subsubsection{The United States}

Until May 2017, the US had national exhaustion, ${ }^{30}$ where a product embodying a patented invention had to be placed on the US market by the patentee in order for there to be exhaustion regarding the US patent. ${ }^{31}$ However, the majority of the US Supreme Court handed down a remarkable decision in Lexmark, ${ }^{32}$ essentially deciding contrary to years of US trade policy.

Lexmark related to toner cartridges produced by Lexmark. Lexmark owned a number of patents for certain components of the cartridges and the manner in which they are used. A 're-manufacture' market had developed for used cartridges, which were refilled and sold at a lower price than Lexmark's new cartridges. In order to discourage this secondary market, Lexmark's business model included a 'Return Program', whereby customers could buy a cartridge with a 20 per cent (or thereabouts) discount, in exchange for agreeing to refrain from transferring used cartridges to anyone other than Lexmark. Customers would sign a contract to this end and Lexmark would also install a microchip in the cartridge to technologically enforce the contract, by preventing reuse of the cartridge once empty. However,

26. Heath, 'Exhaustion and Patent Rights' (n 9) at 470 and 477.

27. See also Roussel Uclaf SA v Hockley International Ltd \& Anor (1996) RPC 441.

28. Centrafarm BV and Adriaan de Peijper v Sterling Drug Inc (1974) ECR 1147 (ECJ Case $15 / 74)$.

29. In HTC Corp v Nokia Corp (2013) EWHC 3247 (Pat) at [165], Arnold J stated that he was bound by Betts $v$ Willmott (1871) LR 6 Ch App 239 Lord Hatherly LC, which allows a patentee to place restrictive conditions on artefacts embodying patented inventions.

30. Stemming from Boesch v Gräff, 133 US 697 (1890). See also Jazz Photo Corp v US International Trade Commission, 264 F3d 1094 (Fed Cir 2001).

31. For a discussion on the US approach until May 2017, see JA Rothchild, 'Exhaustion of Intellectual Property Rights and the Principle of Territoriality in the United States' in Calboli and Lee (n 5) 226.

32. Lexmark (n 10). 
re-manufacturers learnt to circumvent the microchips, ${ }^{33}$ and customers continued to on-sell to these re-manufacturers, despite having signed a contract obliging themselves to the contrary. Lexmark had no recourse against the re-manufacturers through contract law, as the contracts were with the customers (and contracts are in personam). Thus, Lexmark brought suit against the re-manufacturers for patent infringement (as patents embody in rem property rights). Lexmark argued that its express prohibition of the reuse and resale of the cartridges (via contract) meant that it retained its patent rights; that is, that there was no exhaustion. The issue was essentially whether one can contract out of the exhaustion of patent rights.

Lexmark was also concerned with re-manufacturers importing used Lexmark cartridges from overseas. Lexmark contended that this infringed their right to import. Lexmark had legally placed the cartridges at issue on the overseas markets. The question was, thus, whether Lexmark's international actions affected their domestic US patent rights. In other words, did selling the embodiment of their patented invention overseas trigger exhaustion of US patent rights?

The Supreme Court in Lexmark was unanimous that the exhaustion of patent rights is automatic. It occurs 'the moment' the embodiment is sold and one cannot circumvent the exhaustion of patent rights via contract. While the single-use/no-sale contractual terms may be enforceable under contract law, 'they do not entitle Lexmark to retain patent rights in an item that it has elected to sell' ${ }^{34}$ Hence, while Lexmark could have brought a breach of contract action against its customers who signed the contract, it did not have a case of patent infringement against the re-manufacturers.

The Supreme Court additionally differentiated between licensing patent rights and selling goods that embody patented inventions. The Federal Circuit had held that it made no sense to allow patentees to place restrictions on patent licensees, but not purchasers of products embodying their inventions. ${ }^{35}$ On appeal, the Supreme Court reversed this, instead stating. ${ }^{36}$

33. This led to a copyright dispute regarding the Digital Millennium Copyright Act and its anti-circumvention provisions, which Lexmark ultimately lost; Lexmark Int'l Inc v Static Control Components, Inc, 387 F3d 522 (6th Cir 2004).

34. Lexmark (n 10) at 5 Roberts CJ. See Molly Shaffer Van Houweling, 'Exhaustion and Personal Property Servitudes' in Calboli and Lee (n 5) 44 at 61-2, discussing whether patentees should be able to have running encumbrances on embodiments of patented inventions and how this can affect the patent incentive. She states: 'at least with regard to the generally inexhaustible rights of reproduction and making, there is a strong case that the costs imposed by the remotecontrol property rights are outweighed by the benefits (as where land servitudes are enforced to serve important land-use planning goals). That is the basic logic of IP protection: the incentive effect relies on IP owners controlling the proliferation of embodiments that might compete in the marketplace with their authorized embodiments. That type of control limits the ruinous competition that could make it impossible for at least some creators and inventors to garner returns on their investments. It is much less clear that adequate incentives depend on IP owners' ability to control downstream use and transfer of authorized embodiments (including use and transfer that requires some de minimis reproduction). And so, to me, the argument for exhaustion stems in part from the costs that are imposed by chattel servitudes, and in part from the lack of justification for enduring those costs except in the limited circumstances in which creators' and inventors' incentives would be undermined in a way that inhibits progress in science and the useful arts' (at 61).

35. $816 \mathrm{~F} 3 \mathrm{~d} 721$ at $743-4$.

36. Lexmark (n 10) at 11-12 Roberts CJ (emphasis added). 
A patentee can impose restrictions on licensees because a license does not implicate the same concerns about restraints on alienation as a sale. Patent exhaustion reflects the principle that, when an item passes into commerce, it should not be shaded by a legal cloud on title as it moves through the marketplace. But a license is not about passing title to a product, it is about changing the contours of the patentee's monopoly: The patentee agrees not to exclude a licensee from making or selling the patented invention, expanding the club of authorized producers and sellers. See General Elec. Co., 272 U.S., at 489-490. Because the patentee is exchanging rights, not goods, it is free to relinquish only a portion of its bundle of patent protections.

A patentee's authority to limit licensees does not, as the Federal Circuit thought, mean that patentees can use licenses to impose post-sale restrictions on purchasers that are enforceable through the patent laws. So long as a licensee complies with the license when selling an item, the patentee has, in effect, authorized the sale. That licensee's sale is treated, for purposes of patent exhaustion, as if the patentee made the sale itself. The result: The sale exhausts the patentee's rights in that item. See Hobbie v Jennison, 149 U.S. 355, 362-363 (1893).

Hence, any authorized sale - whether by the patentee or licensee - results in exhaustion of the patent rights to use, sell and import. ${ }^{37}$ This is regardless of any attempts to contractually restrict the post-sale activities of the purchaser. ${ }^{38}$ Such restrictions then pertain to the chattel, because the patent rights to use, sell and import have exhausted, and the restrictions are, thus, enforceable through contract law and not patent law.

With respect to the importation of used Lexmark cartridges from overseas, the majority opinion held that '[a]n authorized sale outside the United States, just as one within the United States, exhausts all rights under the Patent Act'. ${ }^{39}$ The majority was concerned with patent law being consistent with copyright law, in this respect, seeing little theoretical or practical reason to differentiate between the two fields, especially since both patent and copyright laws implicate many everyday products. ${ }^{40}$ Chief Justice Roberts stated: ${ }^{41}$

Patent exhaustion [as with Copyright], has its roots in the antipathy toward restraints on alienation ... and nothing in the text or history of the Patent Act shows that Congress intended to confine that borderless common law principle to domestic sales. In fact, Congress has not altered patent exhaustion at all; it remains an unwritten limit on the scope of the patentee's monopoly.

Lexmark argued that a sale outside of the US could not exhaust the patent rights relating to a US patent, as the sale had nothing to do with the US patent. Lexmark contended that the patent rights for a US patent could only exhaust once there is an exchange of

37. Ibid, at 13 .

38. Ibid, at 1 Ginsburg $\mathbf{J}$ concurring.

39. Ibid, at 13 Roberts CJ. For a discussion on the trade-offs of a national or international exhaustion approach, see D Hemel and L Larrimore Ouellette, 'Trade and Tradeoffs: The Case of International Patent Exhaustion' (2016) 116 Colum L Re Sidebar 17.

40. Lexmark (n 10) at 13-14 Roberts CJ. See 17 USC §109(a) and Kirtsaeng v John Wiley \& Sons, Inc, 568 US 519 at 525. For a discussion on whether patent and copyright laws need to have the same exhaustion rules in the US context, see S Ghosh, 'Patent Exhaustion on Trial in the United States', in M Perry (ed), Global Governance of Intellectual Property in the 21st Century (Springer, Heidelberg 2016) 51.

41. Lexmark (n 10) at 14 Roberts CJ. 
payment for the exhaustion, that is, a domestic sale. ${ }^{42}$ The Supreme Court did not agree, noting that the territorial limit does not support Lexmark's argument, because: ${ }^{43}$

Exhaustion is a separate limit on the patent grant, and does not depend on the patentee receiving some undefined premium for selling the right to access the American market. A purchaser buys an item, not patent rights. And exhaustion is triggered by the patentee's decision to give that item up and receive whatever fee it decides is appropriate 'for the article and the invention which it embodies.' Univis, 316 U.S., at 251.

The majority opinion continues by stating that patent law does not guarantee patentees that they will receive any particular price, or the price they would receive from selling to consumers in the US. Instead, the patent rights to exclude ensure that a 'patentee receives one reward' that the patentee deems to be 'satisfactory compensation', regardless of where that reward is given. ${ }^{44}$ In other words, if a patentee makes a sale outside of the US, the rights to use, sell and import vis-à-vis the US patent exhaust. ${ }^{45}$ It does not matter if the reward or compensation is obtained in a jurisdiction where there is no valid patent in force. Exhaustion of the domestic US patent rights are, thus, not connected to the exhaustion of foreign patent rights. In other words, it is not about parallel patent rights and whether their exhaustion causes the exhaustion of US patent rights, but about the US patentee's actions abroad and whether these cause exhaustion of domestic rights.

Consistent with her dissent in Kirtsaeng regarding international exhaustion of copyright, Ginsburg J dissented on the international aspects of Lexmark, holding that a sale outside the US does not exhaust the patent rights arising from a US patent. ${ }^{46}$ Her Honour was particularly concerned with the territorial nature of patents, stating: ${ }^{47}$

Because a sale abroad operates independently of the U.S. patent system, it makes little sense to say that such a sale exhausts an inventor's U.S. patent rights. U.S. patent protection accompanies none of a U.S. patentee's sales abroad - a competitor could sell the same patented product abroad with no U.S.-patent-law consequence. Accordingly, the foreign sale should not diminish the protections of U.S. law in the United States.

Even in the light of Kirtsaeng, Ginsburg $\mathbf{J}$ was not convinced that copyright and patent law need to be consistent with respect to issues of exhaustion. Her Honour noted that patent law and copyright law are different in one important respect, regarding the question of international exhaustion, this being that copyright is more globally harmonized than patent law, due to the Berne Convention, ${ }^{48}$ which also requires that Members of the Union protect the works of authors from other Union Members. This might be correct, though the Paris Convention ${ }^{49}$ and TRIPS Agreement ${ }^{50}$ have harmonized patent

42. Ibid, at 15 .

43. Ibid, at 15 (emphasis added).

44. Ibid, at 16, citing Keeler v Standard Folding Bed Co, 157 US 659 at 661 (1895).

45. Roberts CJ, at 16. The Court referred to its prior decisions, Boesch v Gräff (n 30) at 703, which had held that sales in Germany, which were legal but had nothing to do with the US patent owners, did not exhaust the US patent rights, and the US patent owners could prevent importation. 46. Lexmark (n 10) at 2 Ginsburg J dissenting.

47. Ibid, at 2 .

48. WIPO, Berne Convention for the Protection of Literary and Artistic Works (adopted on 9 September 1886), as revised at Paris (24 July 1971) and as amended on 28 September 1979.

49. WIPO, Paris Convention for the Protection of Industrial Property, 828 UNTS 303 (adopted on 20 March 1883, entered into force 16 April 1970), as revised at Stockholm (14 July 1967).

50. TRIPS (n 7). 
Table 2 The licence model

\begin{tabular}{|c|c|c|c|c|c|c|}
\hline Subject matter & $\begin{array}{c}\text { Patent rights } \\
\text { upon sale }\end{array}$ & Make & $\begin{array}{l}\text { Use (inc. } \\
\text { import, } \\
\text { keep) }\end{array}$ & Exercise & $\begin{array}{l}\text { Vend/ } \\
\text { sell, } \\
\text { dispose }\end{array}$ & Hire \\
\hline \multirow{2}{*}{$\begin{array}{l}\text { Artefact embodying the invention } \\
\text { (inc. resulting from a process } \\
\text { invention) }\end{array}$} & $\begin{array}{l}\text { Patentee's } \\
\text { remaining } \\
\text { rights }\end{array}$ & $\checkmark$ & $\checkmark$ & $\checkmark$ & $\checkmark$ & $\checkmark$ \\
\hline & $\begin{array}{l}\text { Purchaser's } \\
\text { rights }\end{array}$ & - & $\begin{array}{l}\checkmark \\
\text { implied } \\
\text { licence }\end{array}$ & N/A & $\begin{array}{l}\checkmark \\
\text { implied } \\
\text { licence }\end{array}$ & $\begin{array}{l}\checkmark \\
\text { implied } \\
\text { licence }\end{array}$ \\
\hline
\end{tabular}

law to a certain degree. Adding to the global nature of copyright law, copyright does not require application, examination and registration. Furthermore, the internet and digital technologies have made copyright far more international in nature. In contrast, choosing where to patent is strategic, due to the costs involved, and the physical exigencies related to commercializing most patented inventions exacerbates this.

\subsection{The licence model}

Per the licence model, the patentee retains all patent exclusive rights at all times during the patent term. That is, in contrast to the exhaustion model, a patentee's exclusive rights do not exhaust or disappear upon the legal sale of an embodiment of the patented invention (or some other event). Instead, the patentee grants (explicitly or impliedly) a licence to the vendee of the artefact to undertake certain actions. For example, if a patentee sells a tool embodying a patented invention, the patentee grants an implied licence to the purchaser to use, on-sell or hire-out that embodiment.

Like the exhaustion approach, the right to make is not covered by the implied licence, as illustrated in Table 2.

Like exhaustion, the implied licence exists to ensure that purchasers of artefacts embodying patented inventions can use their goods with minimum encumbrance, matching their expectations as owners of chattel.

\subsubsection{National level}

The licence approach is grounded in the still-good 1871 case Betts $v$ Willmott. ${ }^{51}$ This stated that the purchaser of an embodiment of a patented invention has an implied licence to use and vend that embodiment like any other chattel, ${ }^{52}$ 'undisturbed and

51. Betts $v$ Willmott (n 29) was adopted in New Zealand in Thomas A Edison v Stockdale (1919) NZLR 276 (SC). The New Zealand Ministry of Economic Development (NZ MED) indicated that Betts $v$ Willmott continued to be good law under the Patents Act 1953 (NZ), as did the UK Intellectual Property Office with respect to the Patents Act 1977 (UK); see New Zealand and United Kingdom submissions regarding the 'Questionnaire on Exceptions and Limitations to Patent Rights', submitted to the WIPO Standing Committee on the Law of Patents (2011) at [60] <http://www.wipo.int/scp/en/exceptions/>. See also Roussel Uclaf SA v Hockley International Ltd \& Anor (n 27); and HTC Corp v Nokia Corp (n 29).

52. Betts $v$ Willmott (n 29) at 245. See also Schütz, (UK) Ltd v Werit (UK) (2013) UKSC 16 at [66] Lord Neuberger (for the Court). 
unrestricted' ${ }^{53}$ The implied licence only pertains to the embodiment, and the right to use and sell it, and does not extend to the right to make the patented invention. ${ }^{54}$

As its name suggests, an implied licence is automatically granted. However, unlike exhaustion in the EU and US, it is possible to explicitly contradict the implied licence. That being said, any restrictive conditions do not necessarily attach to the products upon further transfer. In the 1911 decision National Phonograph Co of Australia $v$ Menck, the Privy Council (on appeal from Australia) rejected the proposition argued by the appellant that the 'conditions imposed by the patentee run with the goods' ${ }^{5}$ Lord Shaw of Dunfermline stated: ${ }^{56}$

the general doctrine of absolute freedom of disposal of chattels of an ordinary kind is, in the case of patented chattels, subject to the restrictions that the person purchasing them in the knowledge of the conditions attached by the patentee, which knowledge is clearly brought home to him at the time of sale, shall be bound by that knowledge, and accept the situation of ownership subject to the limitations.

53. National Phonograph Co of Australia v Menck (1911) 28 RPC 229 at 246 Lord Shaw. 54. This is exemplified by the string of cases relating to the implied licence to repair or 'prolong the life' of an embodiment of a patented invention, but not to make it. See Solar Thomson Engineering Co Ltd v Barton (1977) RPC 537; United Wire Ltd v Screen Repair Services (2000) 4 All ER 353; and Schütz, (UK) Ltd v Werit (UK) (n 52).

55. National Phonograph Co of Australia v Menck (n 53) at 244. Regarding the general "hostility toward the rude surprise of remote-control property', see Shaffer Van Houweling (n 34), who discusses the common law doctrines created in England and the US to limit the ability to create servitudes vis-à-vis real property, including the requirement of actual notice, because of the costs relating to notice of a servitude and not wanting to encumber future owners (at 47-53). She further notes that she was not arguing that the 'seminal cases establishing the doctrines of copyright and patent exhaustion were mere applications of a common law prohibition on chattel servitudes. They were primarily exercises in statutory interpretation - determining the meaning of the exclusive rights to vend copies of copyrighted works and to use and sell articles embodying patented inventions. But these exercises in statutory interpretation were conducted in the shadow of the common law hostility to chattel servitudes, which made the question of statutory interpretation partly whether Congress had spoken clearly enough to invade what would otherwise be the province of the common law, and to validate a legal mechanism that the common law had rejected' (at 59). See also Z Chafee, 'Equitable Servitudes on Chattels' (1928) 41 Harv L Rev 945; Z Chafee, 'The Music Goes Round and Round: Equitable Servitudes and Chattels' (1956) 69 Harv L Rev 1250; and GO Robinson, 'Personal Property Servitudes' (2004) 71(4) U Chi L Rev 1449.

For an opposing view, which argues that judicial decisions in the US do not reflect a disfavour of servitudes on chattel, but show that the courts wish to restrict the scope or domain of intellectual property statutes so that they do not displace other fields of law (such as contract, personal property and competition law), see Duffy and Hynes (n 24). For a response to this, see A Katz, A Perzanowski and GA Rub, 'The Interaction of Exhaustion and the General Law: A Reply to Duffy and Hynes' (2016) 102 Va L Rev Online 8, who argue that common law doctrine and principles have shaped exhaustion in both patent law and copyright law, often as an aid to statutory interpretation. See also H Hovenkamp, 'Patent Exhaustion and Federalism: A Historical Note' (2016) 102 Va L Rev Online 25, who notes that patent exhaustion developed in the US to demarcate between federal law (patent law) and commercial law (predominantly state law). Duffy and Hynes replied to both of these articles in 'Common Law vs. Statutory Bases of Patent Exhaustion' (2017) 103 Va L Rev Online 1.

56. National Phonograph Co of Australia v Menck (n 53) 29 at 246 (emphasis added). Citing Incandescent Gas Light Co v Cantelo (1895) 12 RPC 262 at 264 Wills J (QB) and Betts v Willmott (n 29). See also Dunlop Rubber Co Ltd v Longlife Battery Depot (1958) 19 RPC 473 at 476 Lloyd-Jacob J. 
That is, explicit restrictive conditions negate any implied licence. ${ }^{57}$ This continues to be good law. ${ }^{58}$ However, the vendee must be aware of the conditions at the time of sale and not learn of them ex post. ${ }^{59}$ This was affirmed in 1996 in Roussel Uclaf $v$ Hockley Int'l. ${ }^{60}$ Following National Phonograph Co of Australia v Menck, the acquirer need not have been made aware of the restrictive conditions at the actual point of acquisition, with respect to the exact artefacts being acquired; it is sufficient that the knowledge was brought to the acquirer's attention generally any time before the acquisition. This has been adopted in New Zealand, ${ }^{61}$ and the Supreme Court of Canada in Eli Lilly \& Co v Novopharm Ltd confirmed that this is also the law in Canada. ${ }^{62}$ Jeremy de Beer and Robert Tomkowicz have stated that, by requiring that restrictive conditions be brought home to subsequent purchasers in order for them to be bound by the same, the Canadian Supreme Court, '[i]n practical terms, ... introduced the doctrine of exhaustion into Canadian patent law'. ${ }^{63}$ However, as they themselves note, ${ }^{64}$ the exhaustion approach differs from the licence approach because it states that certain patent rights cease to exist upon a certain action. In contrast, the licensing approach works via implied and explicit licences. If a purchaser is made aware of any restrictive conditions, that purchaser is bound by those licensing terms.

57. National Phonograph Co of Australia v Menck (n 53) at 246. Note: historically, UK and New Zealand patent legislation made void certain restrictive conditions. See Patents and Designs Act 1907 (UK), section 38; Patents Act 1949 (UK), section 57; Patents Act 1977 (UK), section 44; Patents, Designs, and Trade-marks Act 1921 (NZ), section 43; and Patents Act 1953 (NZ), section 66 (all repealed).

58. For example, NZ MED (n 51) at [60], stating: 'The circumstances in which patent rights are exhausted will depend on the conditions under which the patent owner has decided to make the patented product available', and: 'Whether the rights are exhausted or not is likely to depend on any conditions attached to the initial sale by the patentee'.

59. National Phonograph Co of Australia v Menck (n 53) at 248. See also Incandescent Gas Light Co v Cantelo (n 56) at 264-5.

60. Roussel Uclaf SA v Hockley Int'l Ltd \& Anor (n 27) at 443.

61. Thomas A Edison v Stockdale (n 51).

62. See Eli Lilly \& Co v Novopharm Ltd (1998) 2 SCR 129 at [100], citing the PC decision National Phonograph Co of Australia v Menck (n 53), for the statement that: 'Unless otherwise stipulated in the licence to sell a patented article, the licensee is thus able to pass to purchasers the right to use or resell the article without fear of infringing the patent. Further, any limitation imposed upon a licensee which is intended to affect the rights of subsequent purchasers must be clearly and unambiguously expressed; restrictive conditions imposed by a patentee on a purchaser or licensee do not run with the goods unless they are brought to the attention of the purchaser at the time of their acquisition'.

See also Signalisation de Montréal Inc v Services de Béton Universels Ltée (1993) 1 FC 341 at [20] (FCA); Distrimedic Inc v Dispill Inc (2013) FC 1043 at [226]. In Signalisation de Montréal Inc v Services de Béton Universels Ltée, the majority held that the implied licence (of the purchaser of the embodiment of a patented invention) allows the purchaser to sue for infringement as a licensee. All that matters is that the claimant derives his/her rights from the patentee, whether via exclusive licence, implied licence or lease. The majority noted, however, that there would be few cases where such a purchaser suffers any damage other than de minimis.

63. J de Beer and R Tomkowicz, 'Exhaustion of Intellectual Property Rights in Canada' (2009) 25 Canadian Intellectual Property Review 3 at 12.

64. Ibid, at 5 . 
The scope of patent rights has also played out in cases regarding the line between repairing and making, ${ }^{65}$ and self-replicating inventions. ${ }^{66}$

\subsubsection{International level}

The licence approach also applies at the international level. The case law has, however, recognized the territorial nature of patents, and one can only grant an implied licence with respect to patents for which one has the relevant rights. This being the case, case law has differentiated between a patentee and a licensee being the initial vendor.

In Betts $v$ Willmott, the plaintiff owned analogous patents in England and France. Mr Betts manufactured and sold the patented product in France. He objected to the defendant importing the product made in France into England. Lord Hatherley LC famously stated: ${ }^{67}$

I apprehend that, inasmuch as [the patentee] has the right of vending the goods in France or Belgium or England, or in any other quarter of the globe, he transfers with the goods necessarily the licence to use them wherever the purchaser pleases. When a man has purchased an article he expects to have the control of it, and there must be some clear and explicit agreement to the contrary to justify the vendor in saying that he has not given the purchaser his licence to sell the article, or to use it wherever he pleases as against himself.

This statement stands for the proposition that the implied licence exists regardless of where in the world the patentee places the embodiment on the market. Furthermore,

65. United Wire Ltd v Screen Repair Services (n 54); Schütz (UK) Ltd v Werit (UK) (n 52); and Nestec \& Ors v Dualit \& Ors (2013) EWHC 923 (Pat). The right to repair and the right of third parties to make spare parts has similarly been an issue with respect to copyright and the right of reproduction. Rather than using an implied licence approach, the House of Lords, in British Leyland Motor Corp and Ors v Armstrong Patents Co Ltd (1986) 12 RPC 279, held that vendees have a right to repair because either: (1) 'The owner of a car must be entitled to do whatever is necessary to keep it in running order and to effect whatever repairs may be necessary in the most economical way possible. To derive this entitlement from an implied licence granted by the original manufacturer seems to me quite artificial. It is a right inherent in the ownership of the car itself" (at 359 per Lord Bridge of Harwich); or (2) a vendor cannot use retained property rights to restrain the exercise of granted rights (non-derogation of grant) (at 376 per Lord Templeman). However, the Privy Council described British Leyland Motor Corp and Ors $v$ Armstrong Patents Co Ltd as having created an 'exceptional doctrine', and interpreted it narrowly in Kaisha $v$ Green Cartridge Co (HK) Ltd (1997) UKPC 19 at [24].

66. As far as the author is aware, Canada is the only jurisdiction with an implied licence approach that has addressed how the approach might apply with respect to self-replicating technologies or inventions, in Monsanto Canada Inc v Schmeiser (2004) 1 SCR 902. The situation in the UK is regulated under EU law and the Biotech Directive; EC Directive 98/44/EC of the European Parliament and of the Council of 6 July 1998 on the Legal Protection of Biotechnological Inventions (Biotech Directive), OJ L 213/13 30.7.98, Article 9; and Monsanto Technology LLC v Cefetra BV \& Ors (2010) ECR I-06765 (ECJ Case 428/08) (Grand Chamber). Cf Bowman v Monsanto (n 11). For a discussion on this decision, see Jessica C Lai, 'The Exhaustion Doctrine and Genetic Use Restriction Technologies: A Look at Bowman v Monsanto' (2014) 17(5-6) JWIP 129.

67. Betts $v$ Willmott (n 29) at 245 (emphasis added). This is still good law; e.g. HTC Corp $v$ Nokia Corp (n 29) at [154] and [165]. 
the implied licence to use includes the right to import. The conceptualisation of 'to use' as including 'to import' has been adopted in other jurisdictions. ${ }^{68}$ Lord Hatherley LC was also clear that the patentee can expressly exclude the implied licence, but it must be 'brought home' to the licensee/vendee. ${ }^{69}$ Betts $v$ Willmott is limited to cases where it is the patentee who places the embodiment on the overseas market.

In Société Anonyme des Manufactures de Glaces v Tilghman's Patent Sand Blast Co, Tilghman owned patents in England and Belgium. ${ }^{70} \mathrm{He}$ granted Manufactures de Glaces a licence per his Belgian patent. Manufactures de Glaces manufactured in Belgium. Tilghman objected to Manufactures de Glaces importing and selling its wares in England. Because the importer/licensee and patentee/licensor were distinct entities, infringement was found. ${ }^{71}$ Manufactures de Glaces' licence vis-à-vis the Belgian patent gave it no rights with respect to the English patent. Similarly, any rights that Manufactures de Glaces could confer to its purchasers related to the Belgian patent. That is, purchasers of Manufactures de Glaces' product could not then import this into England under the implied licence to use and sell, as the implied licence only pertained to the Belgian patent.

Lest one think that this case law has no modern application, in the 2013 case HTC Corp v Nokia Corp ${ }^{72}$ Arnold J for the UK Patents Court followed Betts $v$ Willmott and Société Anonyme des Manufactures de Glaces v Tilghman. HTC had bought chips for smartphones from Qualcomm in Taiwan, and imported and sold them in the UK. The chips contained patented technology, owned by Nokia. Qualcomm had a written agreement, wherein Nokia had covenanted not to sue Qualcomm with regard to the patent at hand. HTC argued that Nokia had thereby permitted Qualcomm's manufacture of the chips, and HTC was not aware of any restrictive conditions on those chips, such that HTC had a non-territorially restricted implied licence to use and sell the chips.

Arnold $\mathrm{J}$ stated that, if the purchase was from the patentee, the implied licence is not territorially bound, because the patentee can grant a licence for all territories. ${ }^{73}$ If there are restrictive conditions, these only pass on to further purchasers if they are "brought home' to the purchaser. This is consistent with Betts $v$ Willmott.

In contrast, if the purchase was from a licensee, as in HTC Corp v Nokia Corp: ${ }^{74}$

a licence only confers such rights on the licensee as, on the true construction of the relevant document, the parties agreed. If the licensee has no right to sell in the UK, then a purchaser from the licensee cannot be in a better position.

Arnold $\mathrm{J}$ meant that a purchaser cannot be better off vis-à-vis foreign patent rights. A purchaser or subsequent purchaser can technically be in a better position with respect to a local patent, if any restrictive conditions are not 'brought home' to the purchaser, such that they do not apply. In this case, the purchaser can end up with a broader

68. For example, Briscoe \& Co v Washburn \& Moen (1891) 10 NZLR 85.

69. Roussel Uclaf SA v Hockley International Ltd \& Anor (n 27).

70. (1884) $25 \mathrm{ChD} 1$.

71. Applied in Briscoe \& Co v Washburn \& Moen (n 68) at 91; National Phonograph Co of Australia v Menck (n 53); and HTC Corp v Nokia Corp (n 29) at 157.

72. HTC Corp v Nokia Corp (n 29).

73. Ibid, at [164].

74. Ibid, at [166] see also [169]. 
implied licence than the licensee was allowed to grant. This is consistent with Société Anonyme des Manufactures de Glaces v Tilghman.

\section{A COMPARISON}

Prior to the US Supreme Court decision in Lexmark, a patentee could contract out of exhaustion, ${ }^{75}$ which meant that the US exhaustion model had similarities with the licence approach. ${ }^{76}$ As discussed above, this was overruled in Lexmark, bringing US law into line with EU law. This is quite different from the licence approach, where the implied licence can be explicitly contradicted. ${ }^{77}$ The implied licence relates to the patent rights, which do not exhaust under the licence approach. Under the exhaustion approach, any single-use/no-sale contractual terms pertain to the chattel, as the patent rights to use, sell and import have exhausted.

Under the exhaustion model, if a vendee violates contractual conditions, a patentee has no recourse against follow-on purchasers. Again, this would be different per the licence approach, under which, for example, Lexmark would have a case against the re-manufacturers if they were aware of the restrictive conditions ${ }^{78}$ For obvious reasons, it was preferable for Lexmark to go after re-manufactures rather than its customers. First, bringing suit against its contracting parties would have created resentment among its consumer base. Second, there are fewer re-manufacturers than there are customers breaching their contracts. Third, as a matter of evidence, it is typically easier to identify the re-manufactures and their actions than it is to identify the customers breaching their contracts.

In Lexmark, the US Government had filed an amicus brief, suggesting a middle ground, whereby foreign sales exhausted US patent rights, unless those rights were expressly reserved. ${ }^{79}$ Notably, this would be the situation under the licence approach, per Betts $v$ Willmott, if the patentee is the one that places the chattel on the overseas market. However, the majority in Lexmark stated that this position was 'largely based on policy rather than principle', founded on vague notions of purchasers' and patentee' expectations. ${ }^{80}$ Moreover, the majority stated that '[e]xhaustion does not arise because of the parties' expectations about how sales transfer patent rights'. ${ }^{81}$ Instead, it has to do with the principle against restraints on alienation. Thus, contractual 'restrictions and location [of sale] are irrelevant; what matters is the patentee's decision to make a sale'. ${ }^{82}$ The Supreme Court ruling, thus, brought its exhaustion approach into complete contradiction with the licence approach.

75. See e.g. Sidney Henry \& Ors v AB Dick Co, 32 S Ct 364 (1912); and ES Rogers, 'Restrictions on the Use of Patented Articles' (1912) Mich L Rev 608.

76. As noted by Heath, 'Exhaustion and Patent Rights' (n 9) at 423.

77. Regarding the ability to contract around exhaustion and the potential of 'pliability rules', see A Smith Rinehart, 'Contracting Patents: A Modern Patent Exhaustion Doctrine' (2010) 23(2) Harv JL \& Tech 483.

78. If they were not aware of the restrictive conditions, the patentee could try to argue that the re-manufacturers had 'made' the patented invention. See United Wire Ltd v Screen Repair Services (n 54); Schütz (UK) Ltd v Werit (UK) (n 52); and Nestec \& Ors v Dualit \& Ors (n 65).

79. Lexmark (n 10) at 16-17 Roberts CJ.

80. Ibid, at 17 .

81. Ibid.

82. Ibid, at 18 . 
One should note that the majority in Lexmark did not clarify when one should deem that it was the patentee in the importing country that placed the artefact on the market in the exporting country. The Justices did not seem to limit this to when it is the same legal entity in both jurisdictions, which is supported by their discussion on exhaustion and licensees with respect to domestic issues. Instead, 'exhaustion occurs because, in a sale, the patentee elects to give up title to an item in exchange for payment' ${ }^{83}$ Thus, it would appear that placement on the exporting market via a licensee would suffice, as the patentee receives payment for this. In contrast, while Betts $v$ Willmott stands for the proposition that a patentee's international actions affect all its patent rights, Société Anonyme des Manufactures de Glaces $v$ Tilghman's Patent Sand Blast Co differentiates between a patentee and a licensee. Under either model, there nevertheless remains the issue of how deeply one should investigate beyond the corporate veil. For example, what if the patentee in the exporting country is a subsidiary? Or what if it is set up to appear to be an unrelated legal entity?

Despite being in disagreement, both the approaches of the majority and of Ginsburg $\mathrm{J}$ in Lexmark are markedly different from the licence approach. The majority ruling on international exhaustion proscribes any kind of contractual regulation of patent rights, as they simply exhaust so cannot be contracted around, whereas the licence approach depends on implied and explicit licences because patent rights do not exhaust. Interestingly, the majority approach does share similarities with Betts $v$ Willmott to the extent that the Supreme Court Justices recognized that a singular legal entity's actions can have international effect. At the same time, Ginsburg J's territorial approach would seem to be consistent with the licence approach's recognition that patent rights are territorial (Société Anonyme des Manufactures de Glaces v Tilghman's Patent Sand Blast Co). However, her opinion of absolute territoriality is inconsistent with Betts $v$ Willmott in situations where the patentee in the importing country is the party that places the chattel on the overseas market. While Betts $v$ Willmott stands for the proposition that, in such a case, the patentee's implied licence applies in both jurisdictions (because the patentee has the authority to grant such a licence), under Ginsburg's approach only the patent rights of the jurisdiction where the artefact is sold exhaust.

One could, thus, view the licence approach as falling between the approaches propounded in Lexmark - as shown in Table 3.

\section{Table 3 Comparison of approaches at the international level}

International effect

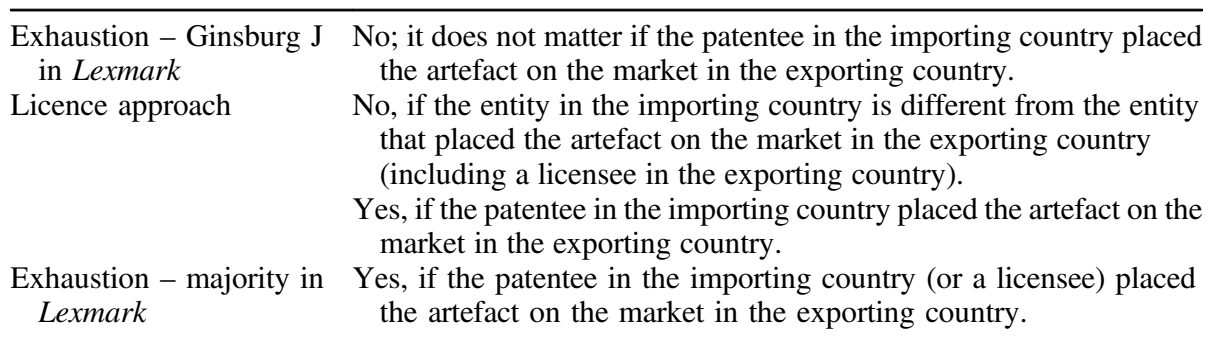

83. Ibid. 
The following illustrates the complexities introduced by having different approaches to patent rights across borders:

A patentee owns a patent in Country X and in Country Y. The patentee sells his/ her wares in Country $\mathrm{X}$ under the contractual condition that the vendee not sell the good outside of Country X. If the vendee then imports the goods into Country Y for the purposes of trade ...

- where Country X and Country Y both have a national exhaustion model, the vendee has infringed the patent from Country Y, but not Country X. In Country $\mathrm{X}$, the patentee only has a breach of contract claim and only against the initial vendee and not any secondary purchasers.

- where Country X and Country Y both have an international exhaustion model, the vendee has not infringed either patent. The patentee has a breach of contract claim against the initial vendee, not any secondary purchasers.

- where Country X has an exhaustion model and Country Y has a licence model, the vendee has infringed the patent in Country $\mathrm{Y}$ because of the explicit condition. The vendee has not infringed the patent in Country $\mathrm{X}$ (due to exhaustion), but has breached the contract.

There are clearly more possible variations. This includes when there is no patent in one of the jurisdictions. If there is no patent, there can be no exhaustion, nor can there be any implied or explicit licence terms in the patent-free jurisdiction (as there are no patent rights to exhaust or license around). However, regardless of whether the importing jurisdiction has US-style exhaustion or licence approach, it would seem that the import of artefacts from patent-free jurisdictions into a patent-protected zone would not constitute patent infringement if it is the patentee that places the artefact on the overseas market. Under the licence approach, unless otherwise explicitly stipulated, a sale by the patentee on an overseas market includes an implied licence to use, exercise and vend the artefact in all the jurisdictions that the patentee has rights in. Regarding the US exhaustion model per Lexmark, there would appear to be no infringement as the patentee has received payment for the good entering the (national or international) market.

Interestingly, the US Supreme Court has also indicated that one can have an implied licence in relation to the right to make. In Bowman v Monsanto, the relevant patent owned by Monsanto pertained to genetically engineered soybeans, which were resistant to Monsanto's Roundup pesticide. ${ }^{84}$ The Court confirmed that upon sale by Monsanto, the rights to use and sell exhausted, but not the right to make. ${ }^{85}$ The right to 'make' the invention remains with the patentee, ${ }^{86}$ and purchasers of physical embodiments of patented inventions may not reproduce it. This is because the "patent holder has 'received his reward' only for the actual article sold, and not for subsequent

84. For an analysis of Bowman v Monsanto (n 11), see Lai (n 66). For a comparison on exhaustion and self-replication technologies in the US, the EU and Canada, see Heath, 'Patent Exhaustion Rules and Self-Replicating Technologies' (n 9).

85. Bowman v Monsanto (n 11) at 4-5.

86. Ibid. 
recreations of it' ${ }^{87}$ The complication was that a purchaser planting (that is, using) the soybeans implicitly made the patented invention. ${ }^{88}$ In the particular case at hand, Monsanto explicitly licensed vendees of its seeds the right to plant (and, thus, the right to make) the seeds, but not save seed. Regarding the possible situation where there is no such explicit licence to plant, the Supreme Court noted: ${ }^{89}$

We do not here confront a case in which Monsanto (or an affiliated seed company) sold Roundup Ready to a farmer without an express license agreement. ... we think that case unlikely to arise ... And in the event it did, the farmer might reasonably claim that the sale came with an implied license to plant and harvest one soybean crop.

Bowman v Monsanto indicated that the US might have a mixed approach; that is, exhaustion of the rights to use, sell and import, but an implied licence approach with respect to the right to make.

\section{UNTANGLING PATENT RIGHTS}

In the Federal Circuit decision of Lexmark v Impression Products, the Court held that a patentee has a bundle of rights and need not hand over the full bundle of rights upon every sale. ${ }^{90}$ The Federal Circuit stated that a patentee can expressly withhold a stick from the bundle, such as the right to sell (and, thus, on-sell). Essentially, the Federal Circuit decided consistently with the doctrine of nemo dat quod non habet, that an owner can choose to pass on whatever rights from the bundle he/she chooses and only these can be on-sold. On this, the Supreme Court stated: ${ }^{91}$

The misstep in this logic is that the exhaustion doctrine is not a presumption about the authority that comes along with a sale; it is instead a limit on 'the scope of the patentee's rights.' United States $v$ General Elec. Co., 272 U.S. 476, 489 (1926) (emphasis added). The right to use, sell, or import an item exists independently of the Patent Act. What a patent adds-and grants exclusively to the patentee-is a limited right to prevent others from engaging in those practices. See Crown Die \& Tool Co. v Nye Tool \& Machine Works, 261 U.S. 24, 35 (1923). Exhaustion extinguishes that exclusionary power. See Bloomer, 14 How., at 549 (the purchaser 'exercises no rights created by the act of Congress, nor does he derive title to [the item] by virtue of the ... exclusive privilege granted to the patentee'). As a result, the sale transfers the right to use, sell, or import because those are the rights that come along with ownership, and the buyer is free and clear of an infringement lawsuit because there is no exclusionary right left to enforce.

This statement conflates the rights to the intangible invention and the rights over the embodiment. It is true that the rights to use, sell and import exist independently from patent law, as any person has the right to use, sell or import their invention (within the confines of the law, of course), and patent law merely gives that person the right to exclude others from the same. ${ }^{92}$ Furthermore, the law relating to choses in possession

87. Ibid, at 5 .

88. In contrast, the Canadian Supreme Court was unanimous that similar behaviour did not constitute making; Monsanto Canada Inc v Schmeiser (n 66) at [26] McLachlin CJ and Fish J; at [142] Arbour J.

89. Bowman v Monsanto (n 11) at fn 3.

90. $816 \mathrm{~F} 3 \mathrm{~d} 721$ at 741.

91. Lexmark (n 10) at 10 Roberts $\mathrm{CJ}$ (emphasis added).

92. Rogers (n 75) at 609-10. 
Table 4 Exhaustion/implied licence of exclusive rights

\begin{tabular}{cll}
\hline $\begin{array}{c}\text { Subject } \\
\text { matter }\end{array}$ & Exclusive rights & Upon sale of embodiment/chattel \\
\hline $\begin{array}{c}\text { Intangible } \\
\text { invention }\end{array}$ & $\begin{array}{c}\text { Patent rights to make, use, } \\
\text { sell and import }\end{array}$ & $\begin{array}{l}\text { Remains: right to make } \\
\text { Exhbodiment }\end{array}$ \\
$\begin{array}{c}\text { Patent rights to make, use, } \\
\text { Chattel }\end{array}$ & $\begin{array}{l}\text { Eell and import } \\
\text { Ordinary personal property licence: rights to use, sell and import } \\
\text { rights }\end{array}$ & $\begin{array}{l}\text { Exhausts/implied licence: rights to use, sell and import } \\
\text { Transfer according to normal property rules. } \\
\text { Affected by contractual terms of sale }\end{array}$ \\
\hline
\end{tabular}

applies to any artefacts embodying patented inventions. However, the exclusive patent rights and the rights stemming from the chose in possession are two separate types of rights, with different, albeit overlapping, subject matter and scope. It is also clear from case law and legislation around the world that patent law confers certain rights over the embodiments of patented inventions, whether they be product or process claims, such that one cannot simply presume what the 'rights that come along with ownership' of the embodiment might be.

It might be helpful to think of the embodiment of the patented invention and the chattel as conceptually distinct; though they are of course the same physical artefact (Table 4). This is because the artefact has both patent-related rights and non-patentrelated rights.

While the sale of an embodiment transfers the rights to use, sell and import with respect to the chattel, it does not transfer those same rights as regards the patented invention, or even necessarily the embodiment. What is dictated by the exhaustion approach is that contract law can affect the non-patent-related rights over the chattel, however the patent-related rights relating to both the intangible invention and the embodiment 'exhaust', and that is why there is no 'exclusionary right left to enforce' (except, of course, the right to make). In contrast, per the licence approach, all the different rights continue to exist, and so must be regulated by an explicit/implied licence to ensure that the purchaser can use the artefact.

The various approaches to the trade of artefacts embodying patented inventions are complicated. That there are differences, and that patents are territorial, muddies the (already murky) waters of international trade. Many of the issues regarding exhaustion or implied/explicit licence stem from the fact that patent law extends its reach into the embodiments of patented inventions. Indeed, while it is said that patents protect something intangible, this is arguably illusory in many cases (compare Tables 5 and 6). ${ }^{93}$

The rights to vend/sell, dispose of and hire can only arise upon the embodying of the invention in chattel. A patent owner (as the owner of personal property) naturally has the right to vend/sell, dispose of or license the patent, but cannot undertake these rights with the intangible invention as claimed. ${ }^{94}$ The right to exercise (a historical

93. See A Pottage and B Sherman, Figures of Invention: A History of Modern Patent Law (OUP, Oxford 2010); A Pottage and B Sherman 'On the Prehistory of Intellectual Property' in Howe and Griffiths (n 6) at 11; and Biagioli (n 6) at 30.

94. See National Phonograph Co of Australia v Menck (n 53) at 245, stating that it is correct not to limit the interpretation of "vend" ... to the idea itself, but extend[ it] to the product of the invention'. 
Table 5 Patent exclusive rights as they pertain to the intangible invention as claimed

\begin{tabular}{|c|c|c|c|c|c|c|c|c|}
\hline Property & Subject matter & Claim type & Make & Use & $\begin{array}{l}\text { Import, } \\
\text { Keep }\end{array}$ & Exercise & $\begin{array}{c}\text { Vend/sell, } \\
\text { dispose }\end{array}$ & Hire \\
\hline \multirow{4}{*}{ Patent } & \multirow{4}{*}{$\begin{array}{l}\text { Intangible invention } \\
\text { as claimed }\end{array}$} & $\begin{array}{l}\text { Product/ } \\
\text { apparatus }\end{array}$ & $\checkmark$ & $\checkmark$ & $\checkmark$ & N/A & N/A & N/A \\
\hline & & $\begin{array}{l}\text { Product-by- } \\
\text { process }\end{array}$ & $\checkmark$ & $\checkmark$ & $\checkmark$ & $\checkmark$ & N/A & N/A \\
\hline & & Use & N/A & $\checkmark$ & N/A & $\checkmark$ & N/A & N/A \\
\hline & & $\begin{array}{l}\text { Process/ } \\
\text { method }\end{array}$ & N/A & $\checkmark$ & N/A & $\checkmark$ & N/A & N/A \\
\hline
\end{tabular}

Table 6 Patent exclusive rights as they pertain to chattel embodying the invention

\begin{tabular}{lcccccccc}
\hline Property & Subject matter & Claim type Make Use & $\begin{array}{c}\text { Import, } \\
\text { Keep }\end{array}$ & Exercise & $\begin{array}{c}\text { Vend/sell, } \\
\text { dispose }\end{array}$ & Hire \\
\hline \multirow{8}{*}{ Patent } & $\begin{array}{c}\text { Product/ } \\
\text { Artefact embodying } \\
\text { the invention (incl. } \\
\text { resulting from } \\
\text { a process invention) }\end{array}$ & $\begin{array}{c}\text { Product-by- } \\
\text { process } \\
\text { Use } \\
\text { Process/ } \\
\text { method }\end{array}$ & $\checkmark$ & $\checkmark$ & $\checkmark$ & N/A & $\checkmark$ & $\checkmark$ \\
& $\checkmark$ & $\checkmark$ & N/A & $\checkmark$ & $\checkmark$ \\
\hline
\end{tabular}

right), can only relate to product-by-process, process or use claims, and not to embodiments (one cannot exercise chattel). The right to use arguably applies to both the intangible invention and its embodiments, as to use an embodiment of a patented invention is to use the intangible invention. The right to make applies to product and product-by-process claims, but not use or process/method claims. However, when it comes to the embodiments, the right to make extends to the products of process claims.

The reason why many of the rights only exist once there is an artefact is that certain rights do not make sense in relation to a disembodied intangible invention. For example, one cannot make a process/method, or sell, dispose of or hire a disembodied invention (though one can sell or license a patent or related right). Moreover, many of the rights that appear upon embodiment exist regardless of patent law; one has the right to vend/sell, dispose of or hire any regular chattel. ${ }^{95}$ However, it is important to keep in mind that patent rights are distinct in character from rights per choses in possession; while selling an artefact embodying a patented invention passes on all rights relating to the chose in possession (unless otherwise agreed), the sale does

95. With respect to US patent law and the point of exhaustion, Duffy and Hynes (n 24) at 37, noted that having exhaustion occur as soon as there is lawful embodiment 'might seem to be an excessively "early" termination of IP rights. Nevertheless, exhausting IP rights upon lawful embodiment in goods would not leave IP rightholders without protection. No one could produce, or produce and sell, goods embodying the intellectual property without the rightholder's permission. Once goods were produced lawfully (that is, with the rightholder's permission), the IP rightholder would have to rely on the general law of property and contract to protect its interests, but there is no necessary reason to believe that general law would be inadequate'. 
not constitute the sale of any patent rights. This is why we have the exhaustion or implied licence models. That is, even though patent rights exist in relation to artefacts embodying patented inventions (some only existing when there is such an embodiment), patent rights are not actually about the physical artefact, but remain about the intangible invention. That being true, it is unclear why the rights to sell and hire extend to the products of process/method claims. The rights that suddenly exist in a product made using/exercising a process/method claim do not track with the intangible invention. In other words, the rights to sell, dispose of and hire in relation to the product do not map onto the rights in relation to the process/method. This is similarly true for the rights to make and use (including to import and keep). However, as discussed below, these are required to ensure that the exclusive right to exploit a process $/ \mathrm{method}$ claim is not circumvented.

In an exhaustion model, where an authorized sale leads to the exhaustion of the rights to sell, dispose of and hire, there is no purpose to these rights. These rights only arise upon embodiment of a patented invention. Say a patentee manufactures such an embodiment. The patentee has in that embodiment the rights to sell, dispose of and hire the invention in the embodiment - rights the patentee also has as owner of a chose in possession. Upon selling that embodiment, those rights to the invention exhaust. Thus, those rights never have any practical relevance. This is especially so when one cannot contract around exhaustion.

Similarly, under the licence approach, it is difficult to ensure that restrictive conditions are brought home to each subsequent purchaser. This means that the rights to import/use, sell, dispose of and hire are almost always covered by an implied licence upon on-sale. These rights are, thus, only relevant vis-à-vis the first purchaser. However, the patentee could simply use contract law to achieve the same ends. Put another way, if restrictive conditions do not run with goods unless brought home to the purchaser, then - for all intents and purposes - patent exclusive rights do not (or only rarely) offer the patentee much more than chattel property and contract law.

Looked at this way, one could view both the exhaustion and the licence models as simplified, at best, and potentially missing the point, at worst. If a patent owner has the right to sell or license a patent (because it is personal property) and can sell or hire out any embodiment of the patented invention (because it is also personal property, as chattel), why does patent law grant the exclusive right to vend/sell and hire? The question is ultimately why patent law extends its reach into embodiments. There will obviously always be a relationship between patents and the embodiments of patented inventions. But, why does patent law grant a patentee extra rights vis-à-vis the embodiment, which do not naturally derive from the rights over the invention as claimed? This is particularly questionable when patent rights exist in products made using patented processes/methods and the rights have nothing to do with the patented claims or are not necessary for the patentee to exclusively exploit those patented claims. Moreover, because they are patent rights and not rights relating to the choses in possession (though both relating to the same physical artefact), they do not pass with an assignment of the chattel the way that normal rights relating to the chattel do.

It would be sufficient that a patentee has the right to make with respect to a product or product-by-process claim, and to use in relation to a use or process/method claim (Table 7). All the other rights are otherwise unnecessary because they are covered by these (keeping in mind that to use has historically had a broad interpretation, including to import and keep), or they are implicit in having chattel (that is, a manufactured product). As the manufacturer, the patentee or his/her licensee will always be able to control first sale. It is unclear why the patentee should have any rights to further sales 
Table 7 Proposed patent exclusive rights

\begin{tabular}{ccccc}
\hline Property & Subject matter & Claim type & Make & Use (incl. import, keep) \\
\hline \multirow{4}{*}{ Patent } & Intangible invention as & Product/apparatus & $\checkmark$ & $\checkmark$ \\
& claimed & Product-by-process & $\checkmark$ & $\checkmark$ \\
& & Use & N/A & $\checkmark$ \\
& & Nocess/method & N/A & $\checkmark$ \\
\hline
\end{tabular}

in the absence of exhaustion or an implied/explicit licence. This is similarly true for the right to hire. One should of course recall that under both the exhaustion and the licence models, the patentee can encumber a product via contract or explicit condition.

The only right that would then have to exhaust or have an implied licence upon a licit sale is the right to use (recalling that the right to make always remains). To the extent that using concurrently makes, there can be an implied licence to make, as illustrated in Bowman v Monsanto. The only situation that this matrix would not cover is where a third party in Country $\mathrm{X}$ uses a process/method, which is not patented in Country X, to manufacture Product ABC, and imports Product ABC into Country Y, where the process/method is patented in Patent 1234. It would also not prevent third parties from replicating such products via a non-patented process/method. These kinds of situations explain why patent law was broadened to protect the products of process/ method claims. However, having the rights to make and use extend over the products of process/method claims would suffice. As alluded to above, this extension into the embodiment is justifiable to ensure a patentee's exclusive exploitation of the rights to make and use method/process claims. In contrast, the rights to vend and hire, and the explicit rights to import and keep, cannot be justified in this way.

Such an approach overcomes issues relating to trying to frame rights around the invention as claimed or the invention as a product, and creating conceptual dissonance between the two.

\section{FINAL THOUGHTS}

This article has highlighted that the scope of patent rights with respect to artefacts embodying patented inventions is heterogeneous around the world. There are differences even within the two main approaches. This diversity, of course, complicates the already complicated world of international trade. It was not the purpose of this article to normatively analyse the two approaches; the exact system that any jurisdiction has should be informed by economic data, legal coherency, and trade, innovation and healthcare policy. This article sought to delineate the scope of patent rights. It concluded that there are too many unnecessary rights, which overlap (because of the historical interpretation of the right to use) or serve no practical purpose (because they only exist upon embodiment in an artefact and then exhaust or are covered by an implied licence upon the licit sale of the artefact). Moreover, the article suggested that the removal of some statutorily specified patent rights would simplify issues relating to patent rights vis-à-vis the artefacts embodying patented inventions. 